\title{
THE WAY ROMANIAN STUDENTS REFER THEMSELVES TO ORTHODOX CHRISTIANITY
}

\author{
Daniela SOREA \\ "Transilvania" University of Brașov, Romania \\ sorea.daniela@unitbv.ro
}

\begin{abstract}
The Romanian Orthodox Church is one of the institutions in which Romanians have great confidence, according to surveys conducted in the country and studies conducted at the level of the European Union in recent years. The results of these researches do not reflect the attitude of young Romanians towards the church. Theoretically coded analysis of 23 essays by sociologist students on their trust or lack of trust in Orthodox Christianity highlights the students' reserve for priests' behavior, communication strategies, financial interests, and their inclination towards opulence. The analysis also highlights the students' tendency to operate with a far wider understanding of things than the canonical concept of Christianity. This tendency, manifests mainly in the declarative separation of faith from church attendance, shows the alignment of students to the post-secular evolutionary direction of European religiosity.
\end{abstract}

\section{Keywords: religiosity, students, Orthodoxy, faith}

\section{Introduction}

In Romania the Orthodox denomination represents the majority and the level of religiosity is deemed high compared to other European countries. The changes in the political regimes at the end of $\mathrm{XX}$ century triggered enthusiastic revitalizations of religious traditions in the Central and Eastern Europe leading to discussions on the appropriateness of introducing religious education in schools.

The current paper highlights Romanian students' relation with Orthodox Christianity. In 2017, students' educational endeavors unfolded alongside with the efforts of the Romanian Orthodox Church (BOR, the church that represents most Romanians) to consolidate religious education in schools and against the background of civil society's critical approaches to the relation between the state and the church. Students' relation with the Orthodox faith inherently reflects the effect of the aforementioned factors. The paper also places this connection in the wider context of the evolution of Western religiosity.

\section{Characteristics and trends of Western religiosity}

According to a Romanian Sociology dictionary, secularization is "a process mostly characteristic of modern age that resides in the tendency to diminish the role of religion in social life" [1]. Dobbleare [2] defines secularization as: the loss of social power by religion and the diminishing of individual piety. Terms like diminishing, loss do not take negative connotations if viewed through a Weberian definition of secularization. On the contrary, they are associated with an increase in individual's 
religious freedom.

Norris și Ingelhart view secularization as irreversible. They argue their position on the subject by indicating the decrease in religiosity all throughout the historical evolution of humanity. In this respect, they provide the example of the countries from the former Soviet Union and Eastern Europe where the fall of communism was followed by an increase in religiosity for only two decades until the stabilization of financial prospects and living condition led to atheism [3]. On the other hand, Lambert [4] signals a decrease in the pace of secularization and a renewal of Christian faith in youth along with the development of "believing without belonging" trend. In this respect, Hamberg [5] regards youth's current position on religion and religiosity as an indicator of secularization.

Secularization enhances atheism. The view of the logical positivism characteristic of the first half of the past century bounds the definition of the scientific method and has consequently impacted the Western Weltanschauung. The analytical doubts concerning the capacity of religion to hold and provide the truth has provided strong arguments against religion and deeply destabilized its comfort zone.

Yet, the alternative is neither accepting atheism as the cognitive destiny of the West, nor welcoming the irreversible character of secularization.

E.M. Hamberg [5] subsumes the term spirituality to the forms of religiosity that become manifest outside traditional religious institutions. The loss of trust in the officially acknowledged religion is accompanied by the development of alternative religious option in the West. For the latter, the individual spiritual experience is more important than dogmas [6] and the divinity the to whom the believers relate must be friendly and flexible [7].

The term spirituality denotes highly varied faiths and practices, some of which more similar to old popular religions and closer to magic than to Christianity. There is a strong re-emergence of paganism in contemporary Europe [8].

Spirituality includes a large number of relations to atheism, such as the critical disengagement from Christianity (a mild form of religious atheism), accepting rational explanations that refer to energies, fields (a form of secular atheism that is scientifically grounded), or even the attempts to retrieve Christianity through the lenses of the new spiritual orientations. Spirituality represents a hard to ignore component of religiosity in contemporary Europe that is complementary to the Christian dimension.

In this context, the fate of secularization becomes nuanced. According to Hamberg [5], if secularization is a decline of Christian religiosity, European countries are undergoing the secularization process. If secularization is the decline of any form of religiosity, the secularization of Europe is not that obvious anymore since the diminished importance of the officially managed religion favors and is countered by the thriving of spiritual movements outside the church. Rorty and Vattimo [9] highlight the post-secular tendency to retrieve Christian love from support, charity, community development, friendly help, and social cohesion.

In Europe's formerly socialist states these features are associated with the effects of having been under an atheist regime. The opinions on the manner in which BOR manages its relation with the post communist state are very different. While Conovici [10], [11] generously credits the Church, Preda [12] and Carp [13] adopt an objective-constructivist approach, whereas Stan and Turcescu [14] are programmatically (and unjustifiably, as Carp considers [13]) critical.

\section{Methodological specifications}

The research conducted with a view to delineating Romanian students' relation with Romanian Orthodoxy is qualitative. By employing theoretical coding, 23 
students' essays on the topic of trust/distrust in Orthodox Christianity are analyzed. The essays are the result of the evaluation protocols for the discipline Sociology of Religion, taught to third year Sociology students from Transylvania University of Brasov. The essays were not mandatory. The students were told that the evaluation would focus on the accuracy of arguments, whereas the position taken (trust/distrust) would not be an evaluation criterion. Until the moment of evaluation, course and seminar activities encouraged objective analysis of all opinions expressed. Therefore, I appreciate that the answers that might be distorted by suspicions concerning the hidden expectations of the evaluator are not significant.

19 of the essay authors are female and four are male. 20 of them are of Orthodox denomination, one is Catholic and two are Neo-Protestants. The essays were analyzed using NVivo 10. Isolated codes were classified by open coding into categories that were then subsumed to some axial categories that are presented below.

\section{Research results}

Numerically speaking, the categories related to opinions expressing trust subsume codes derived from 13 essays, whereas those expressing distrust subsume codes from 21 essays. Inside the latter, when analyzing the data, a number of codes (coming from 13 of the essays) referring to aspects of religiosity that go beyond Christianity could be identified. The sources of the codes do not match up with the distribution of the essays' conclusions. The students often provided both pro- and counter arguments. Looking at the conclusions, the essays present 5 postions for trust, 11 positions against it and seven neutral views.

The arguments of the students who take a positive view towards Orthodox Christianity are presented below in the decreasing order of their appearance in the texts:
- Orthodox Christianity is a family religion (10 essays/ 16 codes). The trust expressed is the result of: having been born and Christened in an Orthodox family, and coming from families practicing their religion and hence teaching them prayers like Angel, My Little Angel» and Our father from the moment they could speak or having them make the sign of the cross every time they would pass by a church which they constantly do even now.

- God loves us (9/24). His love is unconditional, He does not disappoint and is always by His worshippers, knows their needs before expressing them and answers all prayers (it is true that $\mathrm{He}$ does it when and how He best knows), as personal experiences unveil. He does not mind that people remember him only in need.

- Orthodoxy makes us better (8/12). Orthodoxy unites people and makes them "more understanding and kinder", removes hatred and envy. You can understand Orthodoxy if you encounter a gifted priest (4/12) who can guide you, since to believe in God is "to follow Him as it is only too natural", to do charity and pray willingly.

- There is evidence supporting faith (3/7), as there is evidence (even though quite scarce) of Apostle Andrew's presence in Dobrogea. There is also evidence of miraculous healing, icons that cry, healing relics and there were events whose main character was priest Arsenie Boca.

- Orthodox Christianity defines the Romanian people (2/4). "Romanian culture is rooted in the Orthodox religion", religion brings cohesion to people and it is important "to make it an integral part of our behavior, thinking and decisions".

The arguments supporting the distrust in Orthodox Christianity are as follows:

- The church is self-interested (17/59). This is an axial category that has the greatest number of codes that come from most of the essays.

The hierarchs of BOR wear "chains, crosses and a golden mitre", priests "live in luxury, dress in gold, and drive expensive cars". 
Their glamour is the result of taxing (and overtaxing) their services. Worshippers make great efforts to give money to the church and if not they are not visited by the priest on the Twelfth Day and are also marginalized by their communities. You can only light candles bought from the church if you go there. The church does not pay taxes and "The money priests make become theirs and do not go those who actually need it".

Grand "gilded" churches (Romanian People's Salvation Cathedral being one of these) are useless since "you can pray wherever around this world". The church "must be a warm, welcoming, and neat place", the money can be donated, or it can be used to "build a hospital that is so much needed and thus show God's work though people". Religious commands should not be considered more important than "compassion, love and respect", as nor fear of Hell should prevail over morality.

- Orthodox Christianity is logically inconsistent (15/61). The arguments in this category are very diverse. Christian worshippers are fooled since "they are told to fear God, whereas God has never said that". The church controls the masses, manipulates its believers and holds the truth well hidden from the latter. Christianity encourages race and gender discrimination. Women are unjustly subordinated to men in the church. Orthodox Christianity alienates its believers. The Mass is long and difficult to follow, you have to remain kneeling during the whole Mass and genuflect", there is no love in priests' sermons and they do not enlighten the believers. The church severely judges its believers and sometimes its position on certain matters is difficult to understand. That was the case with the tragic fire from the "Colectiv" club when representatives of BOR called the music the victims listened to as satanic and suggested that what had happened had been their fault. The priests are "involved in scandals, rapes, and deeds that are difficult to describe and understood".
Biblical statements and Synods' decisions are hard to grasp, scientifically speaking. For example, "Noah could not have built such a large arc", and "there were no other people inhabiting the Earth so Cain could not have possibly got married". The warrior Stephen the Great is called "the Saint" and the theological differences between the Catholics and the Orthodox are not that big to justify the Great Schism. There are crimes, incurable diseases and sick children and it is difficult to understand how a "good, forgiving and merciful" God allows them. Religion has led to numerous wars and sometimes Christianity was violently imposed.

The presence of icons is difficult to understand in a religion that commands "Thou shall not make unto thee graven images". Moreover, the status of relics in Orthodoxy is difficult to understand. As for Christening, that should take place when its subject understands what happens.

- Orthodox Christianity has lost its mission (15/30). Moderate faith is comfortable, relieves of responsibilities, and ensures a good spot within the community but that is not right. The superior attitude of priests who can absolve from $\sin$ is not right either. The church "is and will be the greatest and most influential political power in history" and sometimes, from a historical perspective, has proven more powerful than states but it has not always used that to "unite people despite racial, gender, education, rank, social and financial status differences". The mission of the church is to guide people to attain eternal life. "There are so many cathedrals and yet you do not get to feel any purity when entering them".

- Trusting Orthodoxy but not Orthodox priests (12/31). The Romanian saying "Act as the priest advises and not as the priest acts". There are a lot of serious accusations against clerics in the public space and there are priests involved in scandals, including "homosexuality, a practice that they publically disdain but in which they engage 
in their private life". "The Romanian Orthodox Church is increasingly perceived as a «state in state» that despises laic rules while upholding its own rules that are not exactly of an orthodox nature".

- There is a divine energy (13/31). The codes and subcategories classified in this axial category indicate that students' faith options are for a spirituality that transcends the canonical bounds of Christianity.

There is a divine power that guides people, "God is actually energy to be found in everything and everywhere", within us, people, and not "just in churches or prayers". Therefore the "the seed of faith bears fruit in all people's souls", our wishes come true and our deeds are justly requited. There is one God but there are more religions. Even Christianity has "numerous pagan traditions": for example Christmas is a celebration that reminds of Sol Invictus. Belief in God is free of rules.

\section{Between the joys of Orthodoxy and the sins of its servants. Discussions and conclusions}

The research delineates the relation of students from Brasov at the end of their undergraduate studies with Orthodox Christianity. Hence, to extend its results is to advance hypotheses. Students' arguments favoring a trusting attitude towards Orthodox Christianity center on the quality of Orthodox experiences. On the other hand, those showing distrust argue it as a loss of status that is explicitly or implicitly associated to the downfall of church representatives who are too anchored in worldly issues. The arguments to not undermine the essence of Orthodoxy, but express the disappointment of prospective believers with the manner in which BOR builds and manages public image, as well as its relation with the believers. The students who do not trust Orthodox Christianity wish they had. They are not atheist but their dissatisfaction is generated by the disagreement between the mission of the Orthodox Church and its activities.
The students of other denominations argue against the Orthodox faith highlighting priests' material preoccupations, the consumerist character of many Orthodox celebrations whose real meanings are unknown to the Orthodox believers, the cult of icons, duration of Mass and the restrictions placed on women's behavior when entering churches.

Theoretically, the sample employed for this research is saturated. Nonetheless, it is imbalanced in terms of genre representation. None of the male essay authors argue in favor of Orthodox Christianity. Such positioning suggests (as a working hypothesis) a lower availability on behalf of men to credit Orthodoxy regardless of the sanctionable behavior of BOR and of its representatives.

Romanians' religiosity scores very high in Europe [15], but for the first time after 1989 their trust in the Orthodox Church decreased below 50\% in October 2017 [16] and the arguments presented by students reflect that. What bad things are happening inside BOR, how much truth is reflected by the negative news is not the focus of this paper. However, BOR has been failing to improve its image by avoiding to publicly approach a variety of subjects (e.g the spiritual aspects of the charity work conducted by BOR that should not be neglected [13], The relation between the church and the state that should be based on the principles of subsidiarity [12], the presence of icons and inaugural Masses as part of the effort to bless public time and space [11])

If BOR's position on all the issues discussed above were presented in the right manner, its relation with Orthodox believers, even with the critical ones, could be consolidated. On the other hand, it would justify BOR's reluctance to the postsecular downgrading of Christian love to the values of current public policies (a trend to be found in students' essays under the statement "Better hospitals than churches"). That would be proof that the church trusts 
its parishioners. But to do that, BOR should learn how to manage the tension between its voice and the voices of the other social actors, as well as its impossibility to control the flow of information [10].

The codes in the category There is a divine energy show students' open attitude towards a definition of religiosity that is more encompassing than that offered by
Christianity, an attitude which is aligned to the trend indicated by Hamberg [5]. Thus, a change in the image of BOR could reposition youth's religiosity within Orthodoxy since the latter already includes a lot of pre-Christian elements, as M. Eliade shown [17]. However, none of these solutions is a sign of secularization.

\section{References}

[1] Zamfir, C., Vlăsceanu, L. (Eds.), Dicționar de sociologie. București, Babel, 1993, p.535.

[2] Dobbleare, K., The Meaning and Scope of Secularization, in P. B. Clarke (ed.), The Oxford Handbook of the Sociology of Religion, Oxford, Oxford University Press, pp. 599-615, 2011.

[3] Norris, P., Inglehart, R., Sacred and secular: Religion and politics worldwide, Cambridge,Cambridge University Press, 2012.

[4] Lambert, Y., New Christianity, Indifference and Diffused Spirituality, in H. Mcleod and W. Ustorf (Eds.), The Decline of Christendom in Western Europe 1750-2000, Cambridge, Cambridge University Press, pp. 63-78, 2003.

[5] Hamberg, E. M., Unchurched Spirituality, in P. B. Clarke (Ed.), The Oxford Handbook of the Sociology of Religion, Oxford, Oxford University Press, pp. 742-757, 2011.

[6] Wenzel, N.G., Postmodernism and religion, in P. B. Clarke (Ed.), The Oxford Handbook of the Sociology of Religion, Oxford, Oxford University Press, pp. 172-193, 2011.

[7] Nolen, S., Give them Jesus, but Hold the Theology, in Globe and Mail (2 Jan.), A1, 1999.

[8] Sorea, D., Two Particular Expressions of Neo-paganism, in Bulletin of the Transilvania University of Brașov, Vol. 6 (55), No.1, Series VII - Social Sciences and -40 åq pp. 29

[9] Rorty, R., Vattimo, G., Viitorul religiei. Solidaritate, caritate, ironie, Pitești, Paralela 45, 2008.

[10] Conovici, I., Ortodoxia în România postcomunistă. Reconstrucţia unei identităţi publice, vol. I, Cluj-Napoca, Eikon, 2009.

[11] Conovici, I., Ortodoxia în România postcomunistă. Reconstrucţia unei identităţi publice, vol. II, Cluj-Napoca, Eikon, 2010.

[12] Preda, R., Semnele vremii. Lecturi social-teologice, Cluj-Napoca, Eikon, 2008.

[13] Carp, R., Religia în tranziţie: ipostaze ale României creştine, Cluj-Napoca, Eikon, 2009.

[14] Stan, L., Turcescu, L., Religie și politică în România postcomunistă, București, Curtea veche, 2010.

[15] http://www.ucatholic.com/blog/10-revealing-maps-religion-europe/

[16] https://www.digi24.ro/stiri/actualitate/social/increderea-romanilor-in-biserica-pentruprima-data-sub-50-808920

[17] Eliade, M., Istoria credințelor și ideilor religioase, Iași, Polirom, 2011. 